\title{
THE PROTEIN CONTENT OF SUBCUTANEOUS EDEMA FLUID IN HEART DISEASE ${ }^{1}$
}

\author{
By R. G. BRAMKAMP \\ (From the Department of Medicine, Stanford University, and from the Department of Public \\ Health of the City and County of San Francisco, San Francisco)
}

(Received for publication September 17, 1934)

The principal mechanism in the production of edema in heart failure has been considered to be an increase in the capillary pressure $(1,2)$. Additional factors, possibly of minor importance, are increased capillary permeability due to anoxemia and slight lowering of plasma colloidal osmotic pressure as a result of decrease of plasma proteins. These have been emphasized by Landis and Krogh $(3,4)$. The general opinion, however, is that lowered colloidal osmotic pressure is not a constant finding in heart disease (5). Landis $(3,4)$ demonstrated increased protein filtration in the capillaries of the frog mesentery after oxygen deprivation, and by indirect methods showed the same thing in the arm in man. The protein content of the transudate in Landis' experiments averaged 1.5 per cent. Vančura (20) presents analyses in support of the idea that there is considerable increase in permeability of the capillary wall to protein in chronic heart disease. Haas (6) attributes edema formation to disturbances in the "vital function" of the capillary endothelium with consequent alterations in permeability. He states that in circulatory edema the protein content of the fluid varies directly with the extent of the edema. Drinker $(7,8)$ believes that the normal capillary transudate is similar to lymph in composition, containing 1 to 4 per cent of protein. $\mathrm{He}$ also states that the lymph flow in circulatory edema is even greater than normal, the capillary filtrate presumably changing but little in composition.

Because of the high protein values for capillary transudate in normals (Drinker), after congestion and anoxemia (Landis), and because of the variation in many of the reported figures on cardiac edema fluid, most of which were obtained by methods not now considered reliable, a reinvesti-

\footnotetext{
1 Supported by a grant from the Rockefeller Fluid Research Fund.
}

gation of the protein content of the fluid seemed likely to be of interest.

The reported analyses of the protein content of subcutaneous edema fluids in heart disease are shown in Table I.

\section{TABLE I}

Reported analyses of the protein content of subcutaneous edema fluids in heart disease

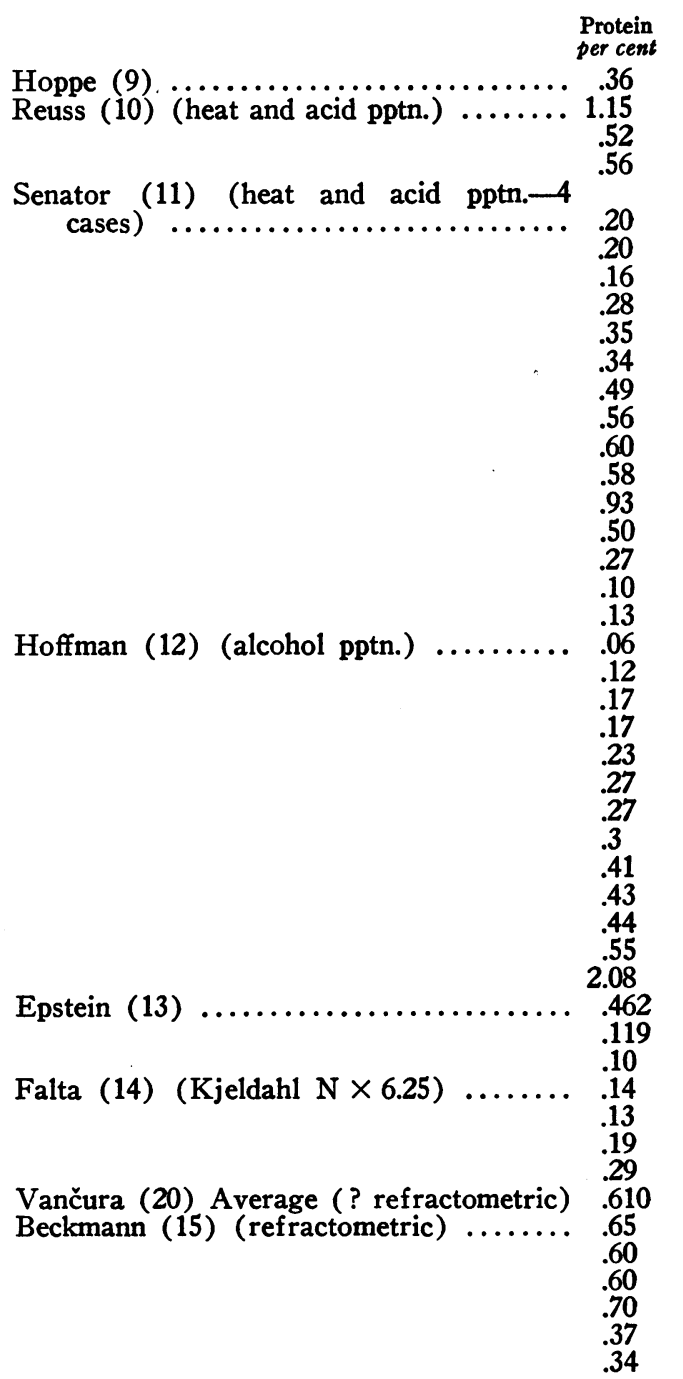


TABLE I-continued

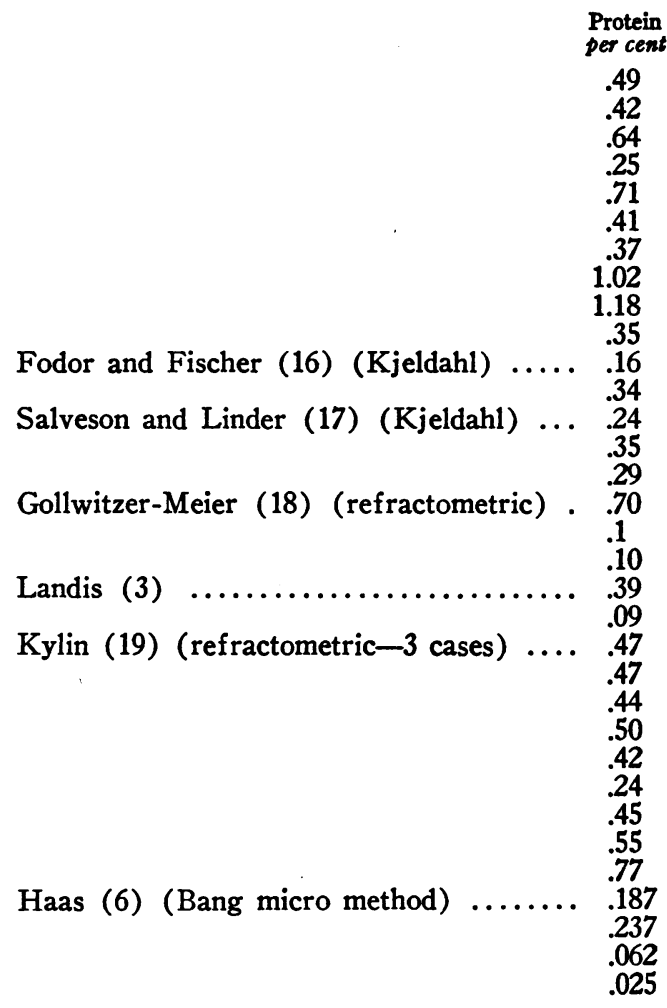

\section{METHOD}

For the present analyses the edema fluid was collected by means of Southey tubes from the legs of patients who had congestive heart failure but no significant degree of anemia or renal failure. Blood samples were taken simultaneously for protein and other determinations. Protein nitrogen determinations were made in duplicate using Howe's (21) method. Because of the small quantity of protein in the fluids fractional precipitation was not attempted, but a number of the fluids mixed with 22.2 per cent sodium sulfate (Howe) gave no precipitate or at most a very faint turbidity indicating an almost complete absence of globulin by this method of testing.

The results obtained from the analyses of 26 fluids from the same number of patients are given in Table II.

The plasma protein values are lower than normal and are of the same order as those reported in heart disease by Payne and Peters (22). While the protein values for the edema fluid show considerable variation, they tend to be lower than most of those previously reported except for a
TABLE II

Plasma protein and edema fluid protein from 26 patients

\begin{tabular}{|c|c|c|}
\hline Patient & $\begin{array}{l}\text { Plasma protein } \\
\text { grams per } 100 \text { cc.* }\end{array}$ & $\begin{array}{l}\text { Edema fluid protein } \\
\text { grams per } 100 \text { cc." }\end{array}$ \\
\hline 1. & $\ldots \ldots \ldots \ldots \ldots \ldots 5.76$ & .16 \\
\hline & 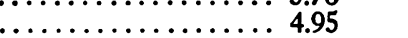 & .14 \\
\hline & $\ldots \ldots \ldots \ldots \ldots \ldots \ldots \ldots 6.29$ & .08 \\
\hline & $\ldots \ldots \ldots \ldots \ldots \ldots \ldots \ldots 5.14$ & .12 \\
\hline & $\ldots \ldots \ldots \ldots \ldots \ldots \ldots .73$ & .54 \\
\hline & $\ldots \ldots \ldots \ldots \ldots \ldots \ldots 5.92$ & .05 \\
\hline & $\ldots \ldots \ldots \ldots \ldots \ldots 5.5$ & .07 \\
\hline 8 . & $\ldots \ldots \ldots \ldots \ldots \ldots \ldots \ldots .5$ & .13 \\
\hline 9 & $\ldots \ldots \ldots \ldots \ldots \ldots \ldots, 6.2$ & .24 \\
\hline 10 & $\ldots \ldots \ldots \ldots \ldots \ldots \ldots \ldots 5.94$ & .20 \\
\hline 11. & $\ldots \ldots \ldots \ldots \ldots \ldots .64$ & .14 \\
\hline 12 & …............ & .33 \\
\hline 13. & $\ldots \ldots \ldots \ldots \ldots \ldots .73$ & .03 \\
\hline 14. & $\ldots \ldots \ldots \ldots \ldots \ldots .7$ & .19 \\
\hline 15 . & $\ldots \ldots \ldots \ldots \ldots \ldots \ldots \ldots 5.01$ & .11 \\
\hline 16 . & $\ldots \ldots \ldots \ldots \ldots \ldots \ldots 4.85$ & 21 \\
\hline 17 & $\ldots \ldots \ldots \ldots \ldots \ldots \ldots .7$ & .10 \\
\hline 18 . & $\ldots \ldots \ldots \ldots \ldots \ldots 6.06$ & .36 \\
\hline & $\ldots \ldots \ldots \ldots \ldots \ldots .62$ & .06 \\
\hline 20 . & $\ldots \ldots \ldots \ldots \ldots \ldots \ldots .5 .09$ & .30 \\
\hline & $\ldots \ldots \ldots \ldots \ldots \ldots \ldots 59$ & .43 \\
\hline 22 . & $\ldots \ldots \ldots \ldots \ldots \ldots \ldots 5.02$ & .35 \\
\hline & $\ldots \ldots \ldots \ldots \ldots \ldots 6.41$ & .35 \\
\hline 24 . & $\cdots \cdots \cdots \cdots \cdots \cdots \cdots \cdots$ & .36 \\
\hline $\begin{array}{l}25 \\
26\end{array}$ & $\cdots \cdots \cdots \cdots \cdots \cdots$ & .14 \\
\hline 6 & t & \\
\hline
\end{tabular}

few Kjeldahl analyses. No relation was noted between either the duration or the extent of the edema and the protein content of the fluid. The low protein content of the fluid would indicate that the degree of capillary damage in the patients studied is insufficient to permit the passage of more than negligible amounts of plasma proteins, and therefore is of little importance as a factor in the production of edema in heart disease. In edematous patients, at least, the fluid in contact with the capillary wall is probably of the same composition as that removed through the Southey tubes, and this "tissue fluid" thus differs markedly from the lymph analyzed by Drinker, and also from the presumptive composition of the capillary transudate estimated indirectly by Landis from his experiments on the effect of venous congestion. This agrees with the idea of Krogh, Landis, and Turner (4) who believe that the fluid bathing the capillaries is of low protein content although it may become more concentrated in protein as it approaches the lymph channels.

It is also to be expected that such small quantities of protein would exert no significant colloidal osmotic pressure to counteract that of the blood proteins, and that the effective colloidal osmotic pressure between the intracapillary and extracapil- 
lary fluids in edematous patients would approach but not quite equal that between plasma and its protein-free filtrate as measured in vitro.

\section{SUMMARY}

1. Concentrations of protein in subcutaneous edema fluids from 26 patients with congestive heart failure varied from 0.03 to 0.54 per cent with a mean value of 0.21 per cent.

2. The low protein concentration in cardiac edema fluids indicates that the factor of capillary damage from anoxemia or other cause is not of importance in the production of cardiac edema.

\section{BIBLIOGRAPHY}

1. Fishberg, A. M., Hypertension and Nephritis. Lea and Febiger, Philadelphia, 1934. 3d ed.

2. Krogh, A., Anatomy and Physiology of Capillaries. Yale University Press, New Haven, 1924. 2d ed.

3. Landis, E. M., Jonas, L., Angevine, M., and Erb, W., The passage of fluid and protein through the human capillary wall during venous congestion. J. Clin. Invest., 1932, 11, 717.

4. Krogh, A., Landis, E. M., and Turner, A. H., The movement of fluid through the human capillary wall in relation to venous pressure and to the colloid osmotic pressure of the blood. J. Clin. Invest., 1932, 11, 63.

5. Meyer, P., Der kolloidosmotische Druck biologischer Flussigkeiten. Ergebn. d. Physiol., 1932, 34, 18.

6. Haas, G., Fragen zur Pathologie des menschlichen Oedems. Ztschr. f. exper. Path. u. Therap., 1921, 22, 375.

7. Drinker, C. K., and Field, M. E., Lymphatics, Lymph, and Tissue Fluid. Williams and Wilkins Co., Baltimore, 1933.

8. Drinker, C. K., and Field, M. E., The protein content of mammalian lymph and the relation of lymph to tissue fluid. Am. J. Physiol., 1931, 97, 32.

9. Hoppe, F., Ueber seröse Transudate. Virchow's Arch. f. path. Anat., 1856, 9, 245.

10. Reuss, A., Beiträge zur klinischen Beurtheilung von
Exsudaten und Transsudaten. Deutsches Arch. f. klin. Med., 1879, 24, 583.

11. Senator, H., Ueber Transsudation und über den Einfluss des Blutdrucks auf die Beschaffenheit der Transsudate. Virchow's Arch. f. path. Anat., 1888, 111, 219.

12. Hoffman, F. A., Der Eiweissgehalt der Oedemflüssigkeiten. Deutsches Arch. f. klin. Med., 1888, 44, 313.

13. Epstein, A. A., Studies on the chemistry of serous effusions. J. Exper. Med., 1914, 20, 334.

14. Falta, W., and Quittner, M., Ueber den Chemismus verschiedener Oedemformen. Wien. klin. Wchnschr., 1917, 30, 1189.

15. Beckmann, K., Odemstudien. I. Untersuchungen über den Eiweissgehalt und intermediären zucker-, Wasser, Harnsäure und Kochsalzwechsel bei verscheidenen Ödemformen. Deutsches Arch. f. klin. Med., 1921, 135, 39.

16. Fodor, A., and Fischer, G. H., Chemische und kolloidchemische Untersuchung des Blutserums und der Ödemflüssigkeit bei Odematösen. I. Beitrag zur Theorie des Ödems. Ztschr. f. d. ges. exper. Med., 1922, 29, 465.

17. Salvesen, H. A., and Linder, G. C., Observations on the inorganic bases and phosphates in relation to the protein of blood and other body fluids in Bright's disease and in heart failure. J. Biol. Chem., 1923, 58, 617.

18. Gollwitzer-Meier, K., Zur Ödempathogenese. Ztschr. f. d. ges. exper. Med., 1925, 46, 15.

19. Kylin, E., Studien über den kolloidosmotischen Druck. IX. Uber den kolloidosmotischen Druck des Blutserums und der Odemflussigkeit bei akuten Glomerulonephritiden und Graviditatsnephritiden. Ztschr. f. d. ges. exper. Med., 1930, 73, 328.

20. Vančura, A., Altérations de la perméabilité des parois capillaires dans les maladies du couer et des reins. I. Etude du liquide des epanchements de séreuses et des oedêmes. Arch. d. mal. d. reins., 1931, 6, 147.

21. Howe, P. E., The determination of proteins in blood -A micro method. J. Biol. Chem., 1921, 49, 109.

22. Payne, S. A., and Peters, J. P., The plasma proteins in relation to blood hydration. VIII. Serum proteins in heart disease. J. Clin. Invest., 1932, 11, 103. 